\title{
Development and test of an associated vaccine Welshicolisan against gastrointestinal bacterioses of pigs
}

\author{
G. Ryzhenko, \\ Candidate of Biological Sciences \\ Gorbatiuk O., \\ Andriyashchuk V., \\ Zhovnir 0. \\ Candidates of Veterinary Science \\ Ukhovska T., \\ Tiutiun S. \\ Institute of Veterinary Medicine, NAAS
}

The purpose. To develop efficient associated vaccine against the most spread bacterioses of pigs. Methods. Microbiological, biological, serological, statistical. Microscopic studies are carried out, features of growth of cultures of isolates-originators of bacteriemic diseases are studied. Results. Probes have confirmed antigenic activity of the vaccine as at inoculated rabbits titres of specific antibodies were authentically enlarged. The adjuvanticity of the specimen ensured preservation of $83,3 \%$ of the vaccinated white mice after infestation with originators $C$. Perfringens and E. coli. Immunobiological reorganization of an organism of the vaccinated pigs is confirmed by titres of specific agglutinins, and economic efficiency - by preserved expenditures in pigbreeding equipments at rate of $240-320$ thousand hrn for a year. Conclusions. Economically efficient antigenactive highly-immunifacient vaccine Welshicolisan against anaerobic dysentery, contagious enterotoxaemia, hydropic illness, and colibacteriosis of animals is developed.

Key words: clostridiosis, associated vaccine, adjuvanticity.

At present in Ukraine, the trade and economic relations and transport flows, there are risks of proliferation biological threats primarily diseases of bacterial etiology. Therefore, problems of the bakteriosis and their associated flow is relevant, because on animals constantly influencing factors associated with disorders of growing technology, way of maintenance, care and feeding of animals, which act as stress for the animals and lead to a reduction of non-specific resistance and bakteriosis in pigs [1-3]. In recent years bacteriological monitoring of confirmed special role in the pathogenesis associated microflora bakteriosis animals, because studies 2-3 and more isolated pathogens in microbiota and only partially - one pathogen isolates $[4,5]$.

To protect the animals from diseases of bacterial etiology and their complicated course there is an urgent need to develop new associated vaccines [6,7]. The advantage associated vaccine preparations is that they can create intense immunity in the body of animals vaccinated simultaneously against several kinds of pathogens that contribute to the improvement and stabilization of the epizootic situation on a number of infectious diseases caused by bacterial pathogens [8-10].

Goal. Develop an effective associated vaccine against the most common bakteriosis of pigs, conduct laboratory quality control of drug research and production testing, to determine the cost-effectiveness of the vaccine after its use in farms.

Materials and methods. Research conducted at the laboratory of anaerobic infections of IVM NAAS, experimental-biological clinic of DU Institute of Cardiology M. D. Strazhesko in the farms: the corporation "Ukragroteh" Khrystynivka district, Cherkasy region.; PSP "Record" Koryukovka district, Chernigiv region.

Used microbiological, biological, serological methods of research, carried out statistical analysis of the results of studies [11-13].

Results. The pilot sample associated vaccine "Velshykolisan" against anaerobic dysentery young animals, infectious enterotoxemia oedematous disease, colibacillosis animals is a compound of antigens selected inactivated strains of epizootic $C$. perfringens and $E$. coli in optimal ratios and immunomodulatory drugs of 
natural origin. Experimental vaccine has passed the quality control laboratory. Inbred white mice instilled test specimens vaccine preparation with subsequent infection of titrated minimal lethal doses of pathogens $C$. perfringens types $B$ and $C$, and $E$. coli. The vaccine provided $83,3 \%$ survival of animals vaccinated with unvaccinated death of $90,0 \%$ white mice, indicating the formation of a high level of protection against specific pathogens above mentioned bacterial infections (Fig. 1).
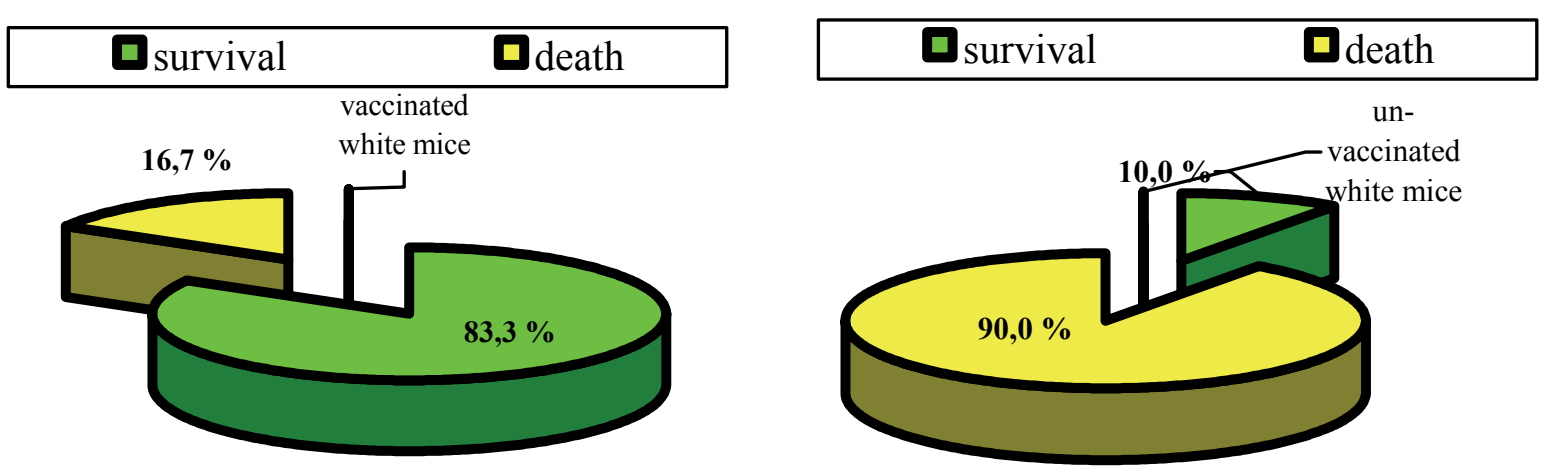

Fig. 1. - Survival of vaccinated and unvaccinated white mice after infection with diurnal C. perfringens cultures types $B$ and $C$, and $E$. coli

An important indicator of the quality vaccine is the biosynthesis of specific antibodies, which characterizes the strength of immunity. In rabbits immunized with the vaccine test specimens defined titers of specific antibodies to antigens $C$. perfringens type $B, C$. perfringens type $C$ and $E$. coli in the blood serum of animals. Analysis of the agglutination test accounting showed that during the period of the experiment the amount of specific antibodies increased significantly compared with previous indicators and rabbits in the control group. The maximum concentration of antibodies to the pathogen $C$. perfringens type $B$, observed 28 days after revaccination when titers of specific antibodies significantly by $51,8 \%(p<0,001)$ exceeded the indicators that have been received in 7 days after the first inoculation of rabbits .

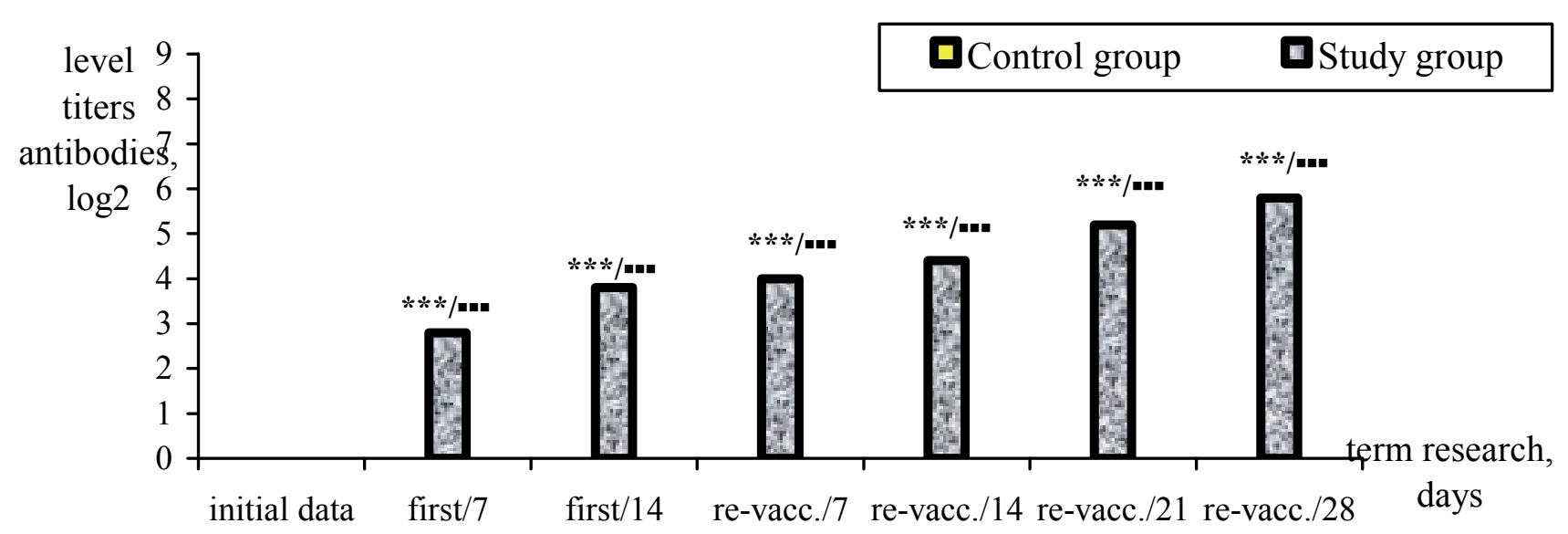

Fig. 2. - Titers of antibodies specific to $C$. perfringens type $B$ in vaccinated rabbits Note. ${ }^{* * *} / \cdots p<0.001$ compared to initial figures and animals in the control group.

About active immunogenesis testified agglutinins indicators, specific to the antitgens of $E$. coli, because there was a probable increase their level at $51,9 \%(p<0,001)$, and the antigen $C$. perfringens type $C$, the level which significantly increased in $30,0(p<0.001)$ times, compared to the original figures and animals in the control group were found in them in 7 days after the first immunization.

For in-depth study of the impact of research on the organism vaccine preparation vaccinated pigs and feasibility of its use in households, we have conducted industrial tests of experimental sample associated vaccine "Velshykolisan" in farms Chernigiv region. - PSP "Record" v. V. Sloboda Koryukovka district and in Cherkasy region - Corporation "Ukragroteh" Khrystynivka district, where there was a high incidence of animals 
that ran symptom of diarrhea by destruction of pigs of different ages and high mortality. After inoculation herds of pigs were conducted serological studies of blood serum of agglutination test by setting the appropriate antigens (Table 1).

Table 1. Titers of specific antibodies in pigs for the experimental sample application associated vaccine "Velshykolisan"; ( $\left.1 \pm m, \log _{2}, n=100\right)$

\begin{tabular}{|c|c|c|c|c|c|c|c|}
\hline \multirow{4}{*}{ 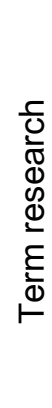 } & \multirow{4}{*}{ 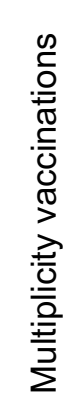 } & \multirow{4}{*}{ 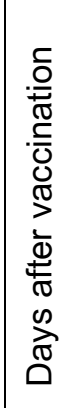 } & \multirow{4}{*}{ Types of antigens } & \multicolumn{4}{|c|}{ A household name, district, region } \\
\hline & & & & \multicolumn{2}{|c|}{$\begin{array}{l}\text { corporation "Ukragroteh" } \\
\text { Hristinovka } \\
\text { Khrystynivka district } \\
\text { Cherkasy region. }\end{array}$} & \multicolumn{2}{|c|}{$\begin{array}{l}\text { PSP "Record" } \\
\text { V. Sloboda } \\
\text { Koryukovka district } \\
\text { Chernihiv region. }\end{array}$} \\
\hline & & & & \multicolumn{4}{|c|}{ Groups of pigs } \\
\hline & & & & sows & $\begin{array}{c}\text { piglets } \\
(2-4 \text { months })\end{array}$ & sows & $\begin{array}{c}\text { piglets } \\
(2-4 \text { months })\end{array}$ \\
\hline \multicolumn{4}{|c|}{ Number of animals in the group } & 35 & 25 & 20 & 20 \\
\hline \multirow{3}{*}{\multicolumn{3}{|c|}{ Initial data }} & $\begin{array}{l}\text { Cl. perfringens type } \\
\mathrm{B}\end{array}$ & $0,5 \pm 0,03$ & $0,4 \pm 0,04$ & $0,6 \pm 0,05$ & $0,6 \pm 0,02$ \\
\hline & & & Cl. perfringens type $\mathrm{C}$ & $0,5 \pm 0,03$ & $0,4 \pm 0,04$ & $0,5 \pm 0,05$ & $0,6 \pm 0,08$ \\
\hline & & & E. coli & $1,1 \pm 0,09$ & $0,8 \pm 0,11$ & $1,2 \pm 0,10$ & $1,0 \pm 0,08$ \\
\hline \multirow{9}{*}{ 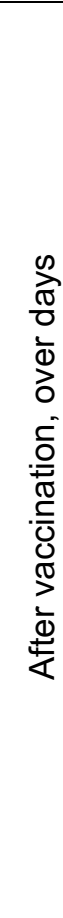 } & & & Cl. perfringens type B & $\begin{array}{r}4,1 \pm 0,16_{* * *} \\
\end{array}$ & $3,9 \pm 0,20{ }_{* * *}$ & $\begin{array}{r}4,4 \pm 0,10 \\
* * *\end{array}$ & $\begin{array}{r}4,1 \pm 0,13 \\
* * *\end{array}$ \\
\hline & $\stackrel{\vec{\omega}}{\stackrel{\omega}{*}}$ & $\stackrel{\nabla}{\square}$ & Cl. perfringens type C & $4,4 \pm 0,14_{* * *}$ & $4,{ }^{4 \pm 0,17}$ & $\begin{array}{r}4,7 \pm 0,10 \\
* * *\end{array}$ & $\begin{array}{r}4,1 \pm 0,30 \\
* * *\end{array}$ \\
\hline & & & E. coli & $5,0 \pm 0,16_{* * *}$ & $4,9 \pm 0,17_{* \star *}$ & $\begin{array}{r}5,4 \pm 0,15 \\
* * *\end{array}$ & $\begin{array}{r}4,7 \pm 0,30 \\
* * *\end{array}$ \\
\hline & \multirow{6}{*}{ 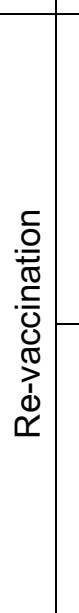 } & \multirow{3}{*}{ 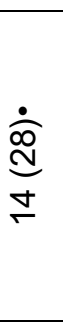 } & Cl. perfringens type B & $5,4 \pm 0,16 \quad$ & ${ }^{4,9 \pm 0,17}$ & $\begin{array}{r}6,0 \pm 0,15 \\
* * *\end{array}$ & $\begin{array}{r}4,6 \pm 0,20 \\
* * *\end{array}$ \\
\hline & & & Cl. perfringens type C & $5,6 \pm 0,11_{* * *}$ & ${ }^{5,4 \pm 0,15}$ & $\begin{array}{r}5,9 \pm 0,15 \\
* * *\end{array}$ & $\begin{array}{r}5,4 \pm 0,20 \\
* * *\end{array}$ \\
\hline & & & E. coli & $\begin{array}{r}6,6 \pm 0,13 \\
* * *\end{array}$ & $\begin{array}{r}6,3 \pm 0,17 \\
* * *\end{array}$ & $\begin{array}{r}7,2 \pm 0,20 \\
* * *\end{array}$ & $\begin{array}{r}6,0 \pm 0,06 \\
* * *\end{array}$ \\
\hline & & \multirow{3}{*}{ 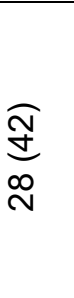 } & Cl. perfringens type B & $6,6 \pm 0,13$ & $6,3 \pm 0,17_{* * *}$ & $\begin{array}{r}7,3 \pm 0,15 \\
* * *\end{array}$ & $\begin{array}{r}5,7 \pm 0,20 \\
* * *\end{array}$ \\
\hline & & & Cl. perfringens type C & $6,8 \pm 0,11_{* * *}$ & $6,6 \pm 0,11_{* * *}$ & $\begin{array}{r}7,2 \pm 0,15 \\
* * *\end{array}$ & $\begin{array}{r}6,3 \pm 0,20 \\
* * *\end{array}$ \\
\hline & & & E. coli & $\begin{array}{r}8,2 \pm 0,15 \\
* * *\end{array}$ & $\begin{array}{r}8,1 \pm 0,15 \\
* * *\end{array}$ & $\begin{array}{r}8,6 \pm 0,25 \\
* * *\end{array}$ & $\begin{array}{r}7,7 \pm 0,20 \\
* * *\end{array}$ \\
\hline
\end{tabular}

Note. ()$\cdot-$ the number of days after the first vaccination; ${ }^{* * *}-p<0,001$ compared with initial values.

According to records of the results established that titers of specific agglutinins in sows and piglets have started to grow significantly in 14 days after the first vaccination.

With the end of the experiment in the sow, which belonged to the corporation "Ukranroteh" and PSP "Record", titers of antibodies specific to $C$. rerfringens type B were significantly higher at $12,3(p<0,001)$ and $13,2$ ( $p<0,001)$; in pigs $2-4$ months age - in 9,5 $(p<0,001)$ times and $15,8(p<0,001)$, respectively. Arguably growing quantitative indicators antibodies specific to $C$. perfringens type $C$ because sows on both farms increased their titles in more than $13,6(p<0,001)$ and the pigs - 10,5 $(p<0,001)$ and $16,5(p<0,001)$ times, respectively. Level agglutinins specific to $E$. coli, grew in sow all farms significantly more than $7,2(p<0,001)$; in piglets - more than 7,7 $(p<0,001)$ times, compared to the initial data.

For analysis of epizootic surveys and economic indices after vaccination of livestock Corporation "Ukragroteh", Cherkasy region. the incidence of pigs decreased by an average of $43,0 \%$ and deaths decreased 
in 2,0 times. The use of vaccine research boosted the average live weight of pigs by $21,0 \%$ and the overall economic effect of the drug was about 240 thousand UAH in a year.

In PSP "Record", Chernihiv region., after application of associated vaccine "Velshykolisan" incidence in pigs decreased twice, mortality - by $38,0 \%$, rising average live weight gain of $15,0 \%$, the economic effect was about 320 thousand UAH per year.

\section{Conclusions.}

Developed associated inactivated vaccine "Velshykolisan" against anaerobic dysentery, infectious enterotoxemia, oedematous disease, colibacillosis animals, laboratory quality control and mounted high antigenic activity and immunogenicity of the drug because it provided 83,3\% survival of mice grafted after their infection titered DLM, against by $90,0 \%$ death unvaccinated mice.

Confirmed immunobiological alteration in the body of vaccinated sows and young pigs, because the use of associated vaccine "Velshykolisan" in sows boosted their level of antibodies specific to C. perfringens type B in 12,3-13,2 ( $p<0,001)$ times; $C$. perfringens type $C$ - to 13,6 $(p<0,001)$ and $E$. coli - in 7,2 (p<0,001) times. After the vaccine piglets $2-4$ months age, increased titers of antibodies to $C$. perfringens type $B-$ at $9,5(p<0,001)$ and 15,8 ( $p<0,001)$; $C$. perfringens type $C-10,5(p<0,001)$; to $E$. coli $-7,7(p<0,001)$ times, respectively, indicating the formation of specific protection in vaccinated pigs to pathogens Perfingens and Escherichia.

Prospects for further research focused on the use of metal nanoparticles in biotechnology manufacturing associated vaccines to enhance their effectiveness.

\section{Bibliography}

1. Nikitenko, A. M., \& Ljasota. V. P., \& Malina V. V. (2004) Metodi doslidzhennja prirodnoï rezistentnosti svinej: Metodichni rekomendaciï [Methods of natural resistance pigs: Methodical recommendations: Guidelines] L'viv [in Ukrainian].

2. Rizhen, V. P., \& Rizhenko, G. F., \& Gorbatjuk O. I. (2013). Etiopatogenetichni osoblivosti formuvannja mikrobiocenoziv za nekrobakteriozu, uskladnenogo asociativnoju mikrofloroju [Etiopathogenetical features of formation for microbiocenosis necrobacteriosis complicated associative microflora] Veterinarna biotehnologija: Bjuleten' № 22. - 2013. - S. 456-467 [in Ukrainian].

3. Rizhenko, V. P. \& Rizhenko, G. F. \& Rizhenko V. V. (2007) Naukove obłruntuvannja naprjamkiv profilaktiki perfringioziv tvarin i ljudej [Scientific substantiation areas prevention Perfringens of animals and people] Veterinarna biotehnologija: Bjuleten' № 11. - 2007. - S. 191-203 [in Ukrainian].

4. Hauer, Paul J. \& Yeary, Teresa J \& Rosenbusch Ricardo F. (2004). Cloning and molecular characterization of the beta toxin (phospholipase $\mathrm{C}$ ) gene of Clostridium haemolyticum//Veterinary Microbiology and Preventive Medicine, College of Veterinary Medicine. - lowa State University.-Ames, IA 50010, USA.- Vol. 10. - Issue 4, P. 243-254.

5. Rizhenko V. P. (2014) Strategija profilaktiki anaerobnih infekcij u tvarinnictvi [Strategy prevention of anaerobic infections in stockbreeding] Visnik agrarnoï nauki. - № 7 [in Ukrainian].

6. Rizhenko, V. P. \& Rizhenko, G. F. \& Gorbatjuk O. I. (2013). Viznachennja optimal'nih spivvidnoshen' antigeniv pri konstrujuvanni asocijovanih vakcin [Determination of the optimal ratio antigens in the designing of associated vaccines] Veterinarna biotehnologija: Bjuleten' № 23. - S. 231-234 [in Ukrainian].

7. Rizhenko, V. P. \& Rizhenko, G. F. \& Gorbatjuk O. I. (2014). Obґruntuvannja biotehnologiï stvorennja asocijovanih vakcin [Justification of biotechnology creation associated vaccines] Veterinarna biotehnologija: Bjuleten' № 24. - S. 198-203 [in Ukrainian].

8. Rizhenko, V. P. \& Rizhenko, G. F. \& Gorbatjuk O. I. (2014). Eksperimental'ne obrruntuvannja efektivnosti zastosuvannja asocijovanoï vakcini «Vel'shikolisan» [Experimental study of the effectiveness associated vaccine "Velshykolisan"] Veterinarna biotehnologija: Bjuleten' № 24. - S. 204-210 [in Ukrainian].

9. Rizhenko, V. P. \& Nichik, S. A. \& Rizhenko, G. F. (2015). Profilaktichni zasobi dlja zahistu svinej proti bakterioziv [Preventive means to protect pigs against bacteriosis] Veterinarna medicina Ukraïni. - № 6. - S. 8-9 [in Ukrainian].

10. Rieznichenko, L. \& Ryzhenko, V. \& Nychyk, S. (2015). Keynote Presentation. Silver nanoparticles in biotechnology of immunobiological preparations development//European Materials Research Society (E-MRS). - E-MRS 2015 Spring Meeting from May 11th to 15 th Lille Grand Palais France: Symposium V Bioinspired and 
Biointegrated Materials as Frontiers Nanomaterials. - Internet-dostup : http://www.emrs-strasbourg.com. [in France].

11. Ivchenko, V. M. \& Sidorchuk, P. I. \& Pavlenko M. S. (1997). Imunologichni metodi doslidzhen' u laboratorijah veterinarnoï medicini: Metodichni rekomendaciï [Methods immunological research in laboratories of Veterinary Medicine: Guidelines] Bila Cerkva, S. 19-20 [in Ukrainian].

12. Ivchenko, V. M. \& Denisenko, G. M. \& Sharandak V. V. (2003). Zagal'ni metodi mikrobiologichnih doslidzhen' u laboratorijah veterinarnoï medicini [General microbiology methods in the laboratories of veterinary medicine:Guidelines ] Bila Cerkva, 64 s. [in Ukrainian].

13. Ojvin I. A. (1960). Statisticheskaja obrabotka rezul'tatov jeksperimental'nyh issledovanij [Statistical alanalisis of experimental results]. Patologicheskaja fiziologija i jeksperimental'naja terapija № 4. - S. 396-401 [in Russian]. 